\title{
Impact of sedimentation history for As distribution in Late Pleistocene-Holocene sediments in the Hetao Basin, China
}

\author{
Hongyan Wang ${ }^{1} \cdot$ Elisabeth Eiche ${ }^{1} \cdot$ Huaming Guo ${ }^{2,3} \cdot$ Stefan Norra ${ }^{1}$
}

Received: 19 February 2020 / Accepted: 23 June 2020 / Published online: 1 July 2020

(C) The Author(s) 2020

\begin{abstract}
Purpose To understand the impact of geochemical sedimentation history for arsenic (As) distribution in the sediment profiles of the Hetao Basin, we (1) evaluated sediments provenance and variations of weathering intensities, (2) attempted to reconstruct the depositional environments, and (3) explored the As and Fe speciation in the sediments. Combining the information above, different sedimentation facies were distinguished in the vertical profiles.

Methods Two sediments cores were drilled up to $80 \mathrm{~m}$ depth. Major and trace element compositions, including rare earth elements (REE), were analyzed. Carbon isotope ratios $\left(\delta^{13} \mathrm{C}_{\mathrm{org}}\right)$ of embedded organic matter in the sediments were analyzed by isotope ratio mass spectrometry (IR-MS). Arsenic and Fe speciation of the sediments were determined by sequential extractions.

Results and discussion The similar REE geochemistry of rocks from the Lang Mountains and sediments in the Hetao Basin indicated that the sediments originated from the Lang Mountains. The $\mathrm{C} / \mathrm{N}$ ratio $(\sim 4$ to $\sim 10)$ in combination with $\delta^{13} \mathrm{C}_{\text {org }}(-27 \%$ o to $-24 \%$ ) suggested that sediments were mainly deposited in aquatic environments. The unconfined aquifer equaled the lacustrine deposit with less intensive weathering during last glacial maximum (LGM). Here, the As content (average, $5.4 \mathrm{mg} \mathrm{kg}^{-1}$ ) was higher than in the aquifer sediments below (average, $3.6 \mathrm{mg} \mathrm{kg}^{-1}$ ).

Conclusion Higher content of releasable As in combination with paleolake-derived organic matter aquifer sediments probably contributes to higher groundwater As concentration in the unconfined aquifer. This study provides the first insight into the impact of sedimentation history on As distributions in sediment profiles in the Hetao Basin.
\end{abstract}

Keywords Sediment basin $\cdot$ Sedimentation history $\cdot$ Arsenic provenance $\cdot$ Weathering intensities $\cdot$ Organic carbon isotopic signature $\cdot$ Arsenic speciation

\section{Introduction}

Responsible editor: Tomas Matys Grygar

Electronic supplementary material The online version of this article (https://doi.org/10.1007/s11368-020-02703-2) contains supplementary material, which is available to authorized users.

Hongyan Wang

hongyan.wang@kit.edu

1 Institute of Applied Geosciences (AGW), Geochemistry \& Economic Geology group, Karlsruhe Institute of Technology (KIT), Adenauerring 20 b, 76131 Karlsruhe, Germany

2 State Key Laboratory of Biogeology and Environmental Geology, China University of Geosciences, Beijing 100083, People's Republic of China

3 School of Water Resources and Environment, China University of Geosciences, Beijing 100083, People's Republic of China
Geogenic groundwater arsenic (As) contamination is of global concern. It is mainly reported from floodplains in South and Southeast Asia including the Ganges-Brahmaputra-Meghna (GBM) River delta, the Mekong River delta, the Red River delta, and inland basins located in the Yellow River catchment including the Hetao Basin, the Hohhot Basin, the Datong Basin, and the Yinchuan Basin (Nordstrom 2002; Rodríguez-Lado et al. 2013; Guo et al. 2017). Over 100 million people are exposed to As with concentration higher than $10 \mu \mathrm{g} \mathrm{L}^{-1}$ (the World Health Organization standard) in the drinking water (Ravenscroft et al. 2009).

Studies indicate that in situ microbial organic carbon oxidation processes coupled with reduction of As-bearing Fe oxy(hydr)oxides is the main cause for As release into groundwater (Nickson et al. 1998; McArthur et al. 2001; Islam et al. 
2004; Van Geen et al. 2004; Stuckey et al. 2015). The adsorbed or incorporated As in the Fe oxy(hydr)oxides is believed to originate from weathering of As-bearing minerals in the source region of the sediments (Zheng et al. 2005; Mukherjee et al. 2014; Xie et al. 2014). Saunders et al. (2005) proposes that intensive weathering of As-bearing bedrocks from the Himalaya in the Holocene epoch increases the As flux into deltas in the South and Southeast of Asia. Already trace or normal concentrations of As in the sediments can induce groundwater As contamination. Therefore, slight differences in the As contents, and more importantly the As speciation, may cause great differences in groundwater As concentration (Guilliot and Charlet 2007; Van Geen et al. 2008; Mukherjee et al. 2014). However, studies about source of As and weathering degrees in different geological settings are insufficient yet.

The depositional environments strongly control the sediment (bio)geochemistry, and thus influence the groundwater As biogeochemical cycling (Dowling et al. 2002; Quicksall et al. 2008; Winkel et al. 2008; McArthur et al. 2011; Wang et al. 2018). In the Mekong Delta, organic carbon and sulfurenriched sediments formed in a paleo-Mangrove depositional environment after the last glacial maximum (LGM). This type of sediment is seen as an important sink for dissolved As. Here, arsenic is either sequestered by the formation of less mobile organic As or incorporated into pyrite (Wang et al. 2018). In West Bengal, the impermeable paleosol of red clay formed during LGM largely protects the underlying aquifer from vertical recharge of As-rich water or dissolved organic matter (McArthur et al. 2011). Depositional environments can be traced by a combined interpretation of $\mathrm{C} / \mathrm{N}$ ratios and $\delta^{13} \mathrm{C}_{\text {org }}$ signatures of organic matter embedded in the sediments (Krishnamurthy et al. 1986; Lamb et al. 2006; Neidhardt et al. 2013; Eiche et al. 2017). Organic matter originating from terrestrial $\mathrm{C} 3\left({ }^{13} \mathrm{C}_{\mathrm{org}} \sim-31\right.$ to $-24 \%$ ) and $\mathrm{C} 4$ plants $\left(\delta^{13} \mathrm{C}_{\text {org }} \sim-16\right.$ to $-12 \%$ o) clearly differs in their $\delta^{13} \mathrm{C}_{\text {org }}$ signatures but has similar $\mathrm{C} / \mathrm{N}$ ratios $(>15)$. The terrestrial material and freshwater organic carbon (POC) can mainly be differentiated by $\mathrm{C}_{\text {org }} / \mathrm{N}$ ratio, which are much lower in the latter case (Fritz and Fontes 1980; Salomons and Mook 1981; Fry and Sherr 1984; Barth et al. 1998). However, systematic research that uses these indicators to better understand the depositional environment in the groundwater As contaminated area is still limited.

The Hetao Basin is a typical arid to semi-arid basin located in the Inner Mongolia (Northern China). The unconfined aquifer (mainly at depths between 10 and $30 \mathrm{~m}$ ), which is the aquifer used for drinking water supply, is severely affected by dissolved As contamination. Here, more than $70 \%$ of groundwater samples exceed $10 \mu \mathrm{g} \mathrm{L}^{-1}$ (Guo et al. 2008; Wen et al. 2013; Cao et al. 2018; Wang et al. 2018). Aquifer sediments deposited in the Late Pleistocene to Holocene are mainly composed of Yellow River bed-load sediments carried from upstream or alluvial/fluvial deposit from the surrounding
Lang Mountains, which both can have different weathering intensities (Cai et al. 2019). Furthermore, the aquifer system in the Hetao Basin is influenced by fluvial-alluvial-lacustrine sedimentation dynamics that took place during the Quaternary epoch (Jia et al. 2016; Yang et al. 2018; Cai et al. 2019). The complex sedimentary framework provides ideal opportunities to study the influence of sedimentation history on As accumulation in or release from the sediments.

Based on the assumption that weathering of As-enriched rocks and the depositional environment will influence the sediment As content and speciation, we want to (1) evaluate the sediment provenance and variations in the weathering intensities by analyzing major and trace element compositions in the sediments, (2) attempt to reconstruct the depositional environments based on the combined interpretation of $\mathrm{C} / \mathrm{N}$ ratio and $\delta^{13} \mathrm{C}_{\mathrm{org}}$ signatures of organic matter embedded in the sediments, and (3) explore the As and Fe speciation in the sediments by applying sequential extraction experiments. The final aim is to distinguish different sedimentation facies throughout the sediment profiles and their relation to sediments As in the respective depth.

\section{Material and methods}

\subsection{Study area}

The Hetao Basin, which covers an area of around $13,000 \mathrm{~km}^{2}$, is located in the Middle part of the Inner Mongolia (Fig. 1a). It is a Cenozoic fault basin that belongs to the Yinchuan-Hetao rift system. It was formed at the end of the Jurassic epoch (Liu et al. 2016). The Hetao Basin is bordered by the Yellow River in the south, the Lang Mountains in the north, the Ulanbuh Desert in the west, and the Wuliangsu Lake in the east (Fig. 1b). The Lang Mountains, which are part of the Central Asian Orogenic Belt (CAOB), are mainly composed of Archean-Mesoproterozoic metamorphic rocks including gneiss, schist, phyllite, slate, and late Paleozoic igneous rocks such as granite and diorite (Wang et al. 2016).

Paleoclimate change and tectonic movement during the Quaternary epoch strongly influenced the sediment deposition in the Hetao Basin. Sediments thickness in the Northwest of the basin (Hangjinhouqi) is in the range of 7000-8000 m. During the Tertiary epoch, red or brown sediments were formed in a shallow paleo lake. This lake developed into the deep lake until the early Pleistocene (Tang et al. 1996). The Yellow River developed its square bend around the Ordos block in the late Miocene-early Pliocene. It flowed through the North of the basin to the Wuliangsu Lake until the onset of the late Pleistocene. Then, it started to flow out of the basin at the beginning of late Pleistocene. As a consequence, the paleolake started to shrink the size until it completely disappeared (Li et al. 2017; Yang et al. 2018). 


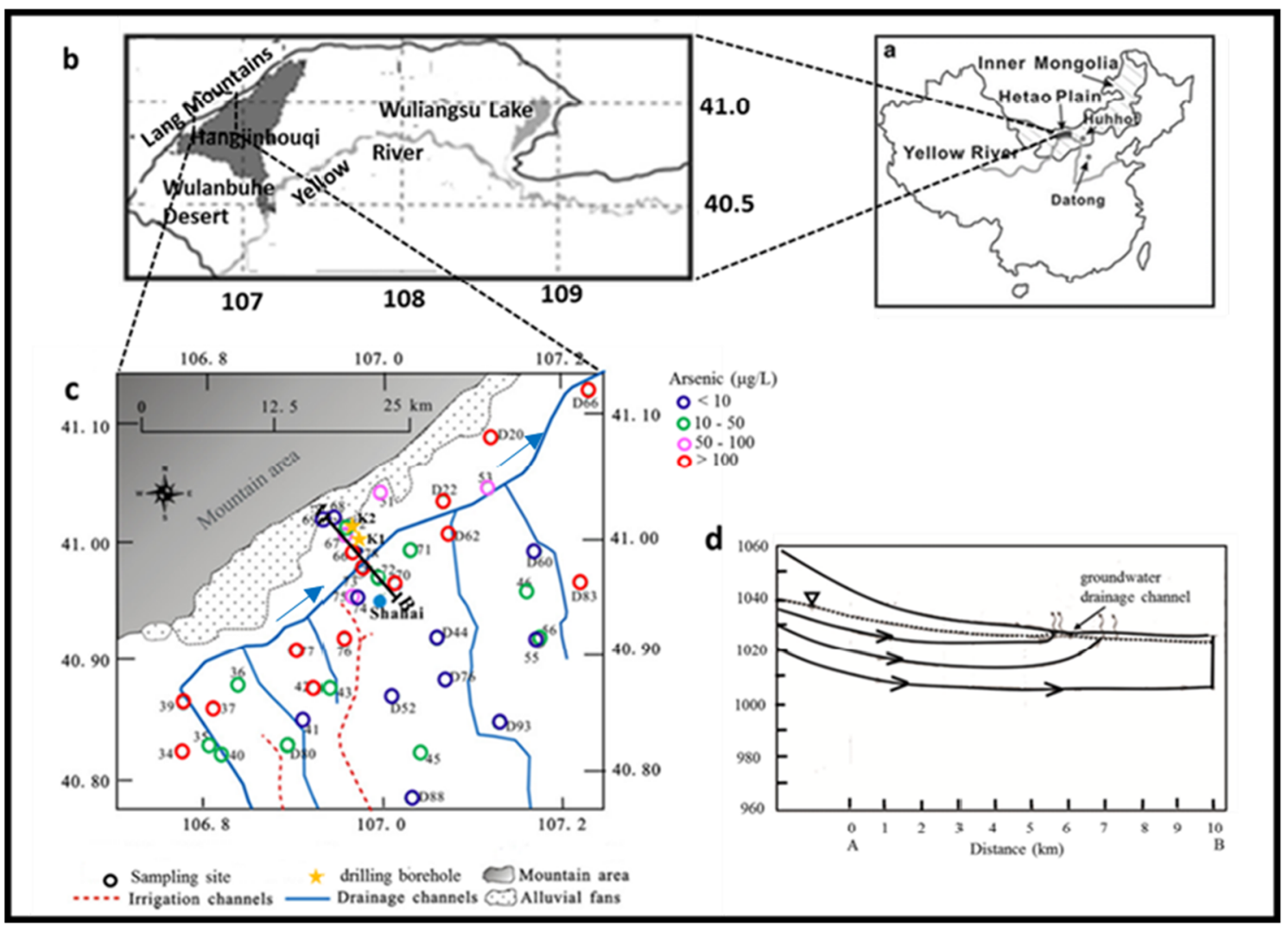

Fig. 1 a Location of the Hetao Basin; b Hetao Basin with Hangjinhouqi, an often-studied area, marked in gray color. $\mathbf{c}$ The known distribution of dissolved As in the study area. The groundwater was collected from handtube wells at depth between 13 and $100 \mathrm{~m}$; the data was previously

Today, the Hetao Basin has a semi-arid to arid climate with annual precipitation of around $200 \mathrm{~mm}$. For detailed hydrogeological information, refer to Zhang et al. (2020). Our study area is located in Shahai $\left(217 \mathrm{~km}^{2}\right)$, an area with serious groundwater As contamination with As concentration up to $720 \mu \mathrm{g} \mathrm{L}^{-1}$ (Fig. 1c). Groundwater that is high in dissolved As is mainly found at depth between 10 and $30 \mathrm{~m}$ (Guo et al. 2008; Cao et al. 2018).

\subsection{Sediments collection}

Two multilevel wells (K1 and K2) were drilled by the CUGB group using rotary drilling equipment in October 2015. Both sites (K1 and K2) are located in the flat plain area, so similar hydrogeological conditions are assumable (Fig. 1c). At the surface, the cores were split into sections of $10 \mathrm{~cm}$ length, capped and placed into $\mathrm{N}_{2}$ purged Mylar bags to avoid oxidation. Aliquots of the sediment samples were transported to Karlsruhe Institute of Technology (KIT) and kept frozen until further analysis. All sediments characterization was done in the Institute of Applied Geoscience at KIT. published by Guo et al. (2012) and partly by Deng et al. (2009). The location of the two sediment cores (K1 and K2) is marked in the map. d Profile A-B showing the groundwater flow direction in the drilling area. The groundwater flow direction was cited from Guo et al. (2011)

\subsection{Major and trace element analysis}

Subsamples of the sediments were freeze-dried and homogenized by mechanical grinding. The trace element geochemistry was determined by means of Energy Dispersive X-ray Fluorescence Spectrometry (EDX; Epsilon 5, PANanalytical). The accuracy (better than $10 \%$ for all elements) of the method was regularly checked by certified standard materials (SOIL-5, $n=4$; GXR-6, $n=4$; GXR-2, $n=4$; SL-1, $n=4$ ). Precision of the repeated standard measurements was better than $5 \%$. The major element geochemistry $(\mathrm{K}, \mathrm{Na}, \mathrm{Si}, \mathrm{Ca}, \mathrm{Mg}, \mathrm{Fe}$, $\mathrm{Mn}, \mathrm{P}, \mathrm{Al}$ ) was analyzed by wavelength dispersive X-ray fluorescence spectrometry (WDX; S4 Explorer, Bruker) using fused beads. The measurement accuracy (within $5 \%$ ) was checked using the certified standard AGV-1 (USGS) and RGM-1.

Total As content in the sediments was additionally determined by HG-FIAS (hydride generation flow injection atomic absorption spectroscopy) measurements after acid digestion. The results of the HG-FIAS were partly crosschecked by measurements using inductively coupled plasma mass spectrometry (ICP-MS) (X-Series, Thermo 
Fisher). Cross-correlation of As concentration determined by HG-FIAS and ICP-MS was $r^{2}=0.99$ (Fig. S1). A detailed description of the acid digestion method is provided in the supplement material. Digestion recovery $(100 \pm 5 \%)$ for As was checked by including the certified standards GXR-5 and RGM-1 into the digestion and measurement procedure. Rare earth elements (REE) including Sc, Y, $\mathrm{La}, \mathrm{Ce}, \mathrm{Pr}, \mathrm{Nd}, \mathrm{Sm}, \mathrm{Eu}, \mathrm{Gd}, \mathrm{Tb}, \mathrm{Dy}, \mathrm{Ho}, \mathrm{Er}, \mathrm{Tm}, \mathrm{Yb}$, $\mathrm{Lu}$, and Th were also measured by ICP-MS after acid digestion. The digestion recovery and measurement accuracy $(100 \pm 10 \%$ for most REE) was checked using the certified standard RGM-1.

The total carbon (TC) content was determined by a carbon/sulfur analyzer (CSA; CS 2000 MultiLine F/SET3, Eltra). Total organic carbon (TOC) was measured with the same instrument after removing inorganic carbon by repeated addition of $\mathrm{HCl}$ (20\%, suprapure, Merck) at $60{ }^{\circ} \mathrm{C}$. The total inorganic carbon (TIC) content was calculated by subtracting the carbon content of decarbonized material (TOC) from untreated material (TC). Measurement accuracy $(100 \pm 2 \%)$ was regularly checked by including a steel standard (92400-3050) into the measurement procedure.

\subsection{Clay mineralogy}

The clay mineralogy was determined using texturized samples by X-ray diffraction (XRD) (Bruker D8, Karlsruhe, Germany). For each selected sample, about $10 \mathrm{~g}$ of sediments was treated with $1 \% \mathrm{HNO}_{3}$ (subboiled) and ammonia solution in the test tubes. After $15 \mathrm{~min}$ in the ultrasonic bath, the samples were left for $3 \mathrm{~h}$ until no muddy deposit was visible. Then, the suspensions were pipetted to glass slides using a 1-mL pipette. Three subsamples were produced. One was air-dried, a second was treated with glycol $\left(60{ }^{\circ} \mathrm{C}\right.$ for $\left.24 \mathrm{~h}\right)$, and the third one was heated at $550{ }^{\circ} \mathrm{C}$. The XRD pattern was recorded at angles between $2^{\circ}$ to $22^{\circ}$. The $\mathrm{CuK}_{\alpha 1}$-radiation was used at $40 \mathrm{kV}$ and $25 \mathrm{~mA}$. Minerals were identified using calibrated spectra by the EVA program (Bruker) and the database of PDF 2002.

\subsection{Extraction method for Fe and As}

A five-step sequential extraction scheme was used to investigate the $\mathrm{Fe}$ and As partitioning in the sediments (Table 1). The modified sequential procedure was based on Keon et al. (2001) and Poulton and Canfield (2005). The $0.5 \mathrm{~g}$ of fresh sediment was weighed into centrifuge tubes. In each extraction step, the appropriate amount of deoxygenated leaching solution was added. Then the sediment-solution mixture was shaken at $300 \mathrm{rpm}$ at room temperature (Table 1). After centrifugation at $4500 \mathrm{rpm}$ for $15 \mathrm{~min}$, all solutions were filtrated using $0.45 \mu \mathrm{m}$ cellulose acetate filters (whatman), and acidified if necessary. Arsenic and Fe concentrations in the leachate were measured by ICP-MS (X-Series, Thermo Fisher). The water content of the sediments was determined gravimetrically after freeze-drying.

\subsection{Analysis of $\mathrm{C} / \mathrm{N}$ ratios and $\delta^{13} \mathrm{C}_{\mathrm{org}}$ signatures}

The determination of carbon/nitrogen $(\mathrm{C} / \mathrm{N})$ ratios and organic carbon isotope $\left(\delta^{13} \mathrm{C}_{\mathrm{org}}\right)$ signature was done in accordance with Neidhardt et al. (2013) and Eiche et al. (2017). Total nitrogen (TN) and carbon content of decarbonated samples $(2 \% \mathrm{HCl}$, Suprapure, Merck) was measured with an elemental analyzer (EuroEA3000, EuroVector). The results of $\mathrm{C}_{\mathrm{org}}$ and $\mathrm{TN}$ measurements were used to calculate molar $\mathrm{C} / \mathrm{N}$ ratios. The measurement accuracy $(100 \pm 5 \%)$ for $\mathrm{C}$ and $\mathrm{N}$ was checked with the reference standards BBOT (HekaTech) and GBW 07043 (office of CRN'S China).

The $\delta^{13} \mathrm{C}_{\text {org }}$ signature for de-carbonated samples was measured using an elemental analyzer (EuroEA3000, EuroVector) in continuous flow mode, which was connected to an isotope ratio mass spectrometer in an open split mode (IR-MS, IsoPrime, Fa. GV Instrument, UK). All $\delta^{13} \mathrm{C}_{\text {org }}$ values of decarbonated samples were reported relative to the Vienna Pee Dee Belemnite (\%o VPDB). The measurement precision, which was controlled by repeated sample (triplicate) and standard (UREA, $n=12$; USGS 24, $n=44$; NBS 18, $n=12$ ) measurements, was better than $\pm 0.1 \%$. The measurement accuracy $(100 \pm 5 \%)$ was controlled using the standard reference values.

\subsection{Calculation method for weathering intensity}

The chemical index of alteration (CIA) is used as a proxy to predict the weathering intensities. It was calculated as follows:

$\mathrm{CIA}=\mathrm{Al}_{2} \mathrm{O}_{3} /\left(\mathrm{Al}_{2} \mathrm{O}_{3}+\mathrm{Na}_{2} \mathrm{O}+\mathrm{K}_{2} \mathrm{O}+\mathrm{CaO} *\right) \times 100$

(Nesbitt and Young 1982)

where $\mathrm{CaO} *$ is $\mathrm{CaO}$ hosted in silicates only. The CIA index was calculated empirically by assuming the same mobilization abilities for $\mathrm{Na}$ and $\mathrm{Ca}$. The $\mathrm{CaO}^{*}$ was assumed to be equivalent to $\mathrm{Na}_{2} \mathrm{O}$ if the remaining number of $\mathrm{CaO}$ moles (after $\mathrm{CaO}$ corrected for phosphate using $\mathrm{P}_{2} \mathrm{O}_{5}$ ) is greater than $\mathrm{Na}_{2} \mathrm{O}$ (Mclennan 1993). The content of $\mathrm{Na}_{2} \mathrm{O}$ was a sum in the sediments including $\mathrm{Na}$ content in the soluble salts, the $\mathrm{CaO}$ content in the sediments of Hetao Basin was greater than the $\mathrm{Na}_{2} \mathrm{O}$ after correcting using $\mathrm{P}_{2} \mathrm{O}_{5}$, therefore $\mathrm{CaO}^{*}$ was assumed to be equivalent to $\mathrm{Na}_{2} \mathrm{O}$. 
Table 1 Sequential extraction scheme used for As and Fe leaching

\begin{tabular}{|c|c|c|c|c|}
\hline Step & Target phase & Extractant & Conditions & Reference \\
\hline $\mathrm{S} 1$ & $\begin{array}{l}\text { Ionically bonded and strongly } \\
\text { adsorbed }\end{array}$ & $1.0 \mathrm{M} \mathrm{NaH}_{2} \mathrm{PO}_{4}$ & $\begin{array}{l}40 \mathrm{~mL}, 24 \mathrm{~h}, \mathrm{pH} 4-5 \text {, one repetition of each time } \\
\text { duration, one water wash }(40 \mathrm{~mL})\end{array}$ & {$[1]$} \\
\hline $\mathrm{S} 2$ & $\begin{array}{l}\text { Co-precipitated with acid volatile } \\
\text { sulfides, carbonates }\end{array}$ & $1 \mathrm{M} \mathrm{CH}_{3} \mathrm{COONa} / \mathrm{CH}_{3} \mathrm{COOH}$ & $\begin{array}{l}40 \mathrm{~mL}, 1 \mathrm{~h}, \mathrm{pH} 4.5 \text {, one repetition, } \\
\text { one water wash }(40 \mathrm{~mL})\end{array}$ & {$[2]$} \\
\hline $\mathrm{S} 3$ & $\begin{array}{l}\text { Co-precipitated with amorphous } \\
\text { iron oxides and magnetite }\end{array}$ & $\begin{array}{l}0.2 \mathrm{M} \text { ammonium oxalate } / 0.17 \mathrm{M} \\
\text { oxalic acid }\end{array}$ & $\begin{array}{c}40 \mathrm{~mL}, 2 \mathrm{~h}, \mathrm{pH} 3 \text {, dark (wrapped in } \mathrm{Al}-\text { foil), } \\
\text { one repetition, one water wash }(40 \mathrm{~mL})\end{array}$ & {$[1]$} \\
\hline S4 & $\begin{array}{l}\text { Co-precipitated with crystalline } \\
\text { Fe oxides }\end{array}$ & $\begin{array}{l}\text { DCB: } 0.5 \mathrm{M} \mathrm{Na} \text {-Citrate }+1 \mathrm{M} \\
\qquad \mathrm{NaHCO}_{3} ; 0.5 \mathrm{~g} \mathrm{Na}_{2} \mathrm{~S}_{2} \mathrm{O}_{4} \mathrm{xH}_{2} \mathrm{O}\end{array}$ & $\begin{array}{l}35 \mathrm{~mL} \mathrm{Na} \text {-Citrate }+2.5 \mathrm{~mL} \mathrm{NaHCO}_{3} \text { (heating to } 85{ }^{\circ} \mathrm{C} \text { ), } \\
\text { addition of } 0.5 \mathrm{~g} \mathrm{Na}_{2} \mathrm{~S}_{2} \mathrm{O}_{4} \times \mathrm{XH}_{2} \mathrm{O}, 15 \mathrm{~min} \text { at } 80{ }^{\circ} \mathrm{C} \text {, } \\
\text { one repetition, one water wash }(40 \mathrm{~mL} \text { ) }\end{array}$ & {$[1]$} \\
\hline S5 & $\begin{array}{l}\text { Co-precipitated with pyrite and part } \\
\text { of sheet silicates }\end{array}$ & $16 \mathrm{M} \mathrm{HNO}_{3}$ & $\begin{array}{l}20 \mathrm{ml} 16 \mathrm{M} \mathrm{HNO}_{3}, 2 \mathrm{~h}, 25^{\circ} \mathrm{C} \text {, one repetition, one } \\
\text { water wash }(40 \mathrm{~mL})\end{array}$ & {$[1]$} \\
\hline
\end{tabular}

[1] Keon et al. (2001), [2] Poulton and Canfield (2005)

\section{Result}

\subsection{Lithology, mineralogy, and geochemical composition of the sediments}

The aquifer sediments that were covered by silty clay or clay layers $(\mathrm{K} 1,0 \sim 10 \mathrm{~m}$; K2, $0 \sim 14 \mathrm{~m})$ were mainly composed of silt to fine sand. A clay layer at $40 \mathrm{~m}$ depth separated the unconfined aquifer from the semi-confined aquifer (Fig. 2). The major minerals in the sediments of study area included quartz and feldspar, with minor contributions from carbonates including calcite and dolomite, mica, and clay minerals (Wang et al. 2019a, b). The clay minerals were mainly composed of chlorite and illite (Fig. S2).

Major element geochemistry was dominated by $\mathrm{SiO}_{2}$ (ranging from 45.6 to $85.5 \mathrm{wt} \%$ with an average value of $66.7 \mathrm{wt} \%$ ), followed by $\mathrm{Al}_{2} \mathrm{O}_{3}$ (ranging from 7.9 to $17.6 \mathrm{wt} \%$ with an average value of $11.2 \mathrm{wt} \%$ ) and $\mathrm{CaO}$ (ranging from 1.6 to $7.2 \mathrm{wt} \%$ with an average value of $3.7 \mathrm{wt} \%$ ). The average $\mathrm{Fe}_{2} \mathrm{O}_{3}$ and $\mathrm{MnO}$ content was $3.7 \%$ and $0.06 \%$, respectively. Discriminant function analysis of major elements showed that sediments were plotted in the quartz sedimentary and felsic igneous region (Fig. 3).
The As content in the sediments ranged from 4.7 to $40.3 \mathrm{mg} \mathrm{kg}^{-1}$ with an average value of $11.2 \mathrm{mg} \mathrm{kg}^{-1}$ (except for peat layers) (Table 2). Cluster analysis showed that As was grouped together with major elements including $\mathrm{Fe}, \mathrm{Mn}, \mathrm{Mg}$, $\mathrm{Al}$, and trace elements including $\mathrm{Pb}, \mathrm{Zn}, \mathrm{Cu}$, and $\mathrm{Ni}$ (Euclidean distance $\leq 5$ ) (Fig. 4). The REE composition of the sediments was summarized in the Table 3. It showed enrichment of the light rare earth elements $\left((\mathrm{La} / \mathrm{Yb})_{\text {chondrite }}=\right.$ 9.6). A significant $\mathrm{Eu}$ anomaly $(\delta \mathrm{Eu}=0.70)$ was visible in comparison with chondrite.

The investigated sediments were depleted in $\mathrm{Na}$ and enriched $\mathrm{Ca}$ compared with the upper continental crust (UCC). Trace element concentrations including $\mathrm{Rb}, \mathrm{Pb}, \mathrm{Mo}$, and As were higher in the investigated sediments compared to the UCC composition. The As enrichment ranged from 0.98 times to 8.4 times the UCC value with an average of 2.3 (Fig. 5a). In comparison with the UCC, the REE content showed a flat distribution pattern with a slightly depleted abundance (Fig. 5b).

\subsection{Proxies of sediment weathering and deposition}

The CIA was applied to understand variation of mineral weathering intensities along the depth profile (Fig. 2).
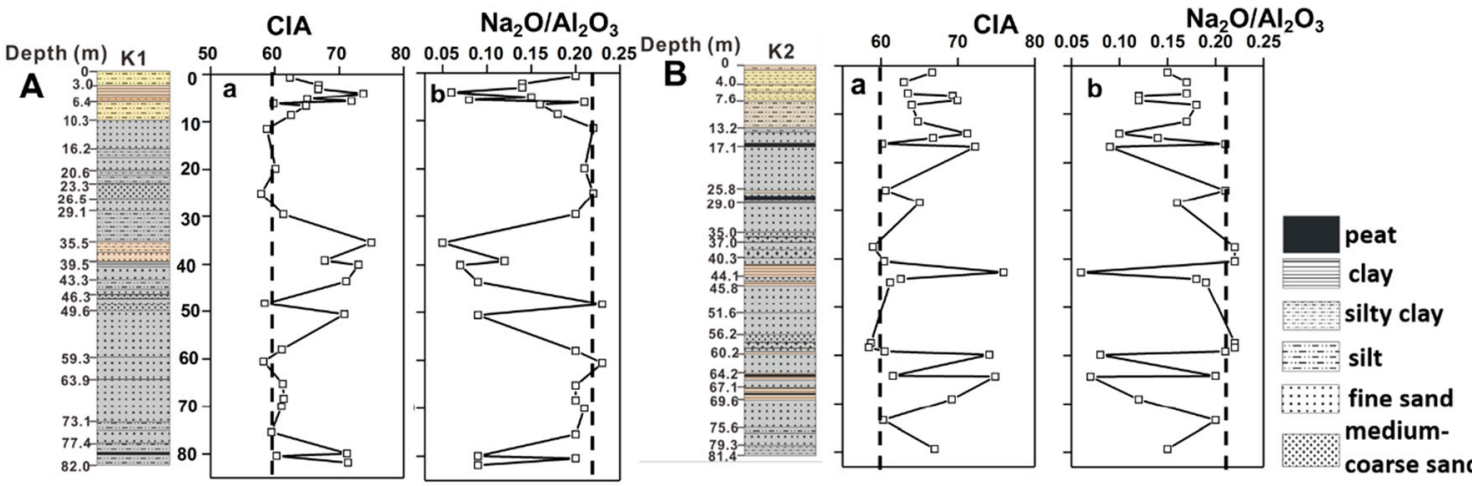

Fig. 2 Chemical index of alteration (CIA) (a) and $\mathrm{Na}_{2} \mathrm{O} / \mathrm{Al}_{2} \mathrm{O}_{3}$ ratio (b) in the depth profiles of $\mathrm{K} 1$ (a) and $\mathrm{K} 2$ (b) 




Fig. 3 Discrimination diagram for sedimentary provenance. $\mathrm{F} 1=30.638$ $\mathrm{TiO}_{2} / \mathrm{Al}_{2} \mathrm{O}_{3}-12.541 \mathrm{Fe}_{2} \mathrm{O}_{3 \text { (Total) }} / \mathrm{Al}_{2} \mathrm{O}_{3}+7.329 \mathrm{MgO} / \mathrm{Al}_{2} \mathrm{O}_{3}+12.031$ $\mathrm{Na}_{2} \mathrm{O} / \mathrm{Al}_{2} \mathrm{O}_{3}+35.402 \mathrm{~K}_{2} \mathrm{O} / \mathrm{Al}_{2} \mathrm{O}_{3}-6.382, \mathrm{~F} 2=56.5 \mathrm{TiO}_{2} / \mathrm{Al}_{2} \mathrm{O}_{3}-10.897$ $\mathrm{Fe}_{2} \mathrm{O}_{3 \text { (Total) }} / \mathrm{Al}_{2} \mathrm{O}_{3}+30.875 \mathrm{MgO} / \mathrm{Al}_{2} \mathrm{O}_{3}-5.404 \mathrm{Na}_{2} \mathrm{O} / \mathrm{Al}_{2} \mathrm{O}_{3}+11.112$ $\mathrm{K}_{2} \mathrm{O} / \mathrm{Al}_{2} \mathrm{O}_{3}-3.89$. The discrimination analysis is cited from Roser and Korsch (1988)

Systematic mineral weathering changing from incipient $(\mathrm{CIA}=50-60)$ over intermediate $(\mathrm{CIA}=60-80)$ to extreme (CIA > 80) weathering could be concluded by the CIA (Fedo et al. 1995). The CIA values of the investigated sediments ranged from 58 to 76 , indicating incipient to intermediate weathering of the sediments. Ratio of $\mathrm{Na}_{2} \mathrm{O} / \mathrm{Al}_{2} \mathrm{O}_{3}$ showed coherent variations with CIA signatures (Fig. 2), suggesting that sediments were dominated by silicate weathering (e.g., plagioclase) connected to $\mathrm{Na}^{+}$removal which was consistent with the $\mathrm{Na}$ depletion in comparison to UCC values (Fig. 2). Chemical weathering in the Hetao Basin was controlled by the climate (especially precipitation and temperatures). This is further indicated by the chlorite and illite as the main clay minerals in the sequence, which formation was limited to semi-arid to arid climate (Fig. S2) (Robert and Kennett 1994).

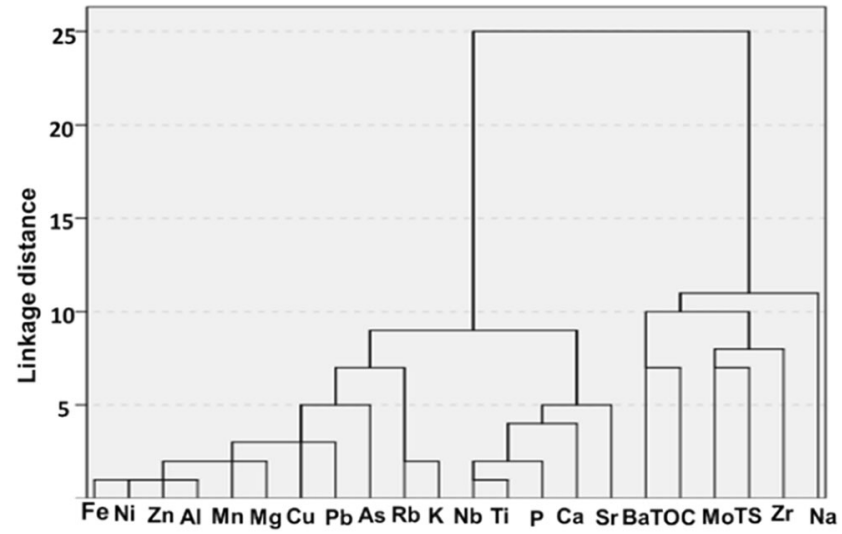

Fig. 4 Dendrogram for 22 variables expressing the statistical distance of different elements in the sediments of K1 and K2 (except peat samples)

Higher CIA values were obtained in the top silty clay and clay layers of $\mathrm{K} 1$ and $\mathrm{K} 2$ (depth less than $\sim 10 \mathrm{~m}$ in $\mathrm{K} 1$ and $\sim 14 \mathrm{~m}$ in $\mathrm{K} 2$ ) with an average value of 66 (Fig. 2). Stronger weathering intensities could be related to the warm and humid climate in the Holocene (Lambeck et al. 2014) when sediment age at a depth of $6 \mathrm{~m}(\sim 8 \mathrm{ka})$ and $9 \mathrm{~m}(\sim 12 \mathrm{ka})$ from previous studies was taken into account (Guo et al. 2011; Liu et al. 2014) (Table S1). The unconfined aquifer sediments lying between $\sim 10 \mathrm{~m}-\sim$ $30 \mathrm{~m}$ showed slightly lower weathering intensities (average CIA $=60$ ). This could be the result of cold climate conditions during the LGM from $\sim 10$ to $\sim 30 \mathrm{ka}$ assuming that the deposition rate was $1 \mathrm{~m} \mathrm{ka}^{-1}$. The peat layers formed at depth of $16.7 \mathrm{~m}$ and $28.4 \mathrm{~m}$ could be related to buried plant material, which was deposited during LGM induced by paleolake regression (Fig. 2). Sediments from a depth of $\sim 30 \mathrm{~m}$ to $\sim 75 \mathrm{~m}$ in $\mathrm{K} 1$ and K2 were composed of a mixture of fine-medium/coarse sand with interbedded clay layers (average CIA $=64$ ). Hydraulic sorting could cause the poorly sorted grain sizes, which was influenced by bursting and flooding of the Yellow River-connected paleolake (Jia et al. 2016; Yang et al. 2018; Cai et al. 2019).

Table 2 Major and trace element geochemical composition of sediments from K1 and K2 (except peat sediments) in the Hetao Basin

\begin{tabular}{|c|c|c|c|c|c|c|c|c|c|c|c|c|}
\hline Element & $\begin{array}{l}\mathrm{SiO}_{2} \\
\text { (wt\%) }\end{array}$ & $\begin{array}{l}\mathrm{K}_{2} \mathrm{O} \\
(\mathrm{wt} \%)\end{array}$ & $\begin{array}{l}\mathrm{Na}_{2} \mathrm{O} \\
\text { (wt\%) }\end{array}$ & $\begin{array}{l}\mathrm{Al}_{2} \mathrm{O}_{3} \\
(\mathrm{wt} \%)\end{array}$ & $\begin{array}{l}\mathrm{CaO} \\
(\mathrm{wt} \%)\end{array}$ & $\begin{array}{l}\mathrm{MgO} \\
\text { (wt\%) }\end{array}$ & $\begin{array}{l}\mathrm{P}_{2} \mathrm{O}_{5} \\
(\%)\end{array}$ & $\begin{array}{l}\mathrm{Fe}_{2} \mathrm{O}_{3} \\
\text { (wt\%) }\end{array}$ & $\begin{array}{l}\mathrm{MnO} \\
(\mathrm{wt} \%)\end{array}$ & $\begin{array}{l}\mathrm{TiO}_{2} \\
\text { (wt\%) }\end{array}$ & $\begin{array}{l}\mathrm{Nb} \\
\left(\mathrm{mg} \mathrm{kg}^{-1}\right)\end{array}$ & $\begin{array}{l}\text { As } \\
\left(\mathrm{mg} \mathrm{kg}^{-1}\right)\end{array}$ \\
\hline Min & 45.6 & 1.76 & 0.92 & 7.88 & 2.18 & 0.74 & 0.05 & 1.61 & 0.02 & 0.19 & 5 & 4.7 \\
\hline Max & 85.5 & 3.56 & 2.35 & 17.60 & 9.39 & 3.87 & 0.19 & 7.15 & 0.12 & 0.66 & 15 & 40.3 \\
\hline Average & 65.7 & 2.42 & 1.66 & 11.2 & 5.34 & 1.85 & 0.10 & 3.72 & 0.06 & 0.43 & 9 & 11.2 \\
\hline Element & $\begin{array}{l}\mathrm{Zr} \\
\qquad \begin{array}{l}(\mathrm{mg} \mathrm{k}- \\
\left.\mathrm{g}^{-1}\right)\end{array}\end{array}$ & $\begin{array}{l}\mathrm{Pb} \\
\qquad \begin{array}{l}(\mathrm{mg} \mathrm{k}- \\
\left.\mathrm{g}^{-1}\right)\end{array}\end{array}$ & $\begin{array}{l}\text { Mo } \\
\qquad(\mathrm{mg} \mathrm{k-} \\
\left.\mathrm{g}^{-1}\right)\end{array}$ & $\begin{array}{l}\mathrm{Sr} \\
\qquad \begin{array}{l}(\mathrm{mg} \mathrm{k}- \\
\left.\mathrm{g}^{-1}\right)\end{array}\end{array}$ & $\begin{array}{l}\mathrm{Ni} \\
\qquad \begin{array}{l}(\mathrm{mg} \mathrm{k}- \\
\left.\mathrm{g}^{-1}\right)\end{array}\end{array}$ & $\begin{array}{l}\mathrm{Zn} \\
\qquad \begin{array}{l}(\mathrm{mg} \mathrm{k}- \\
\left.\mathrm{g}^{-1}\right)\end{array}\end{array}$ & $\begin{array}{l}\mathrm{Cu} \\
\qquad \begin{array}{l}\left(\mathrm{mg} \mathrm{k}^{-1}\right) \\
\left.\mathrm{g}^{-1}\right)\end{array}\end{array}$ & $\begin{array}{l}\mathrm{Rb} \\
\qquad \begin{array}{l}(\mathrm{mg} \mathrm{k}- \\
\left.\mathrm{g}^{-1}\right)\end{array}\end{array}$ & $\begin{array}{l}\mathrm{Ba} \\
\qquad \begin{array}{l}(\mathrm{mg} \mathrm{k}- \\
\left.\mathrm{g}^{-1}\right)\end{array}\end{array}$ & $\begin{array}{l}\text { TOC } \\
(\mathrm{w}- \\
\mathrm{t} \%)\end{array}$ & TS (wt\%) & \\
\hline Min & 74 & 15 & 0.6 & 155 & 10 & 26 & 15 & 68 & 387 & 0.045 & 0.009 & \\
\hline Max & 227 & 37 & 6.4 & 428 & 47 & 107 & 45 & 177 & 692 & 0.896 & 0.544 & \\
\hline Average & 137 & 23 & 1.4 & 222 & 25 & 57 & 27 & 108 & 472 & 0.224 & 0.040 & \\
\hline
\end{tabular}


Table 3 Rare earth elements (REE) concentrations $\left(\mathrm{mg} \mathrm{kg}^{-1}\right)$ in the sediments of $\mathrm{K} 1$ and $\mathrm{K} 2$ from the Hetao Basin

\begin{tabular}{lllllllllllllllllll}
\hline Element & $\mathrm{La}$ & $\mathrm{Ce}$ & $\mathrm{Pr}$ & $\mathrm{Nd}$ & $\mathrm{Sm}$ & $\mathrm{Eu}$ & $\mathrm{Gd}$ & $\mathrm{Tb}$ & $\mathrm{Dy}$ & $\mathrm{Y}$ & $\mathrm{Ho}$ & $\mathrm{Er}$ & $\mathrm{Tm}$ & $\mathrm{Yb}$ & $\mathrm{Lu}$ & $\begin{array}{c}\mathrm{La} / \\
\mathrm{Yb}_{\mathrm{N}}\end{array}$ \\
\hline Min & 11.1 & 21.4 & 2.6 & 9.5 & 1.8 & 0.5 & 1.6 & 0.3 & 1.5 & 8.7 & 0.3 & 0.9 & 0.1 & 0.9 & 0.1 & 8.3 \\
Max & 33.7 & 80.5 & 8.1 & 29.9 & 5.7 & 1.2 & 4.9 & 0.8 & 4.4 & 26.9 & 0.9 & 2.6 & 0.4 & 2.5 & 0.4 & 11.9 \\
Average & 22.6 & 46.9 & 5.3 & 19.6 & 3.8 & 0.8 & 3.2 & 0.5 & 2.9 & 17.1 & 0.6 & 1.7 & 0.2 & 1.6 & 0.2 & 9.6 \\
\hline
\end{tabular}

\subsection{Characteristics of organic matter in the sediments}

The TOC content in the near surface clay or silty clay layers (TOC, $0.11-0.60 \mathrm{wt} \%$ in $\mathrm{K} 1 ; 0.08-0.90 \mathrm{wt} \%$ in $\mathrm{K} 2$ ) was higher compared to the aquifer sediments below. The $\delta^{13} \mathrm{C}_{\text {org }}$ values showed an increasing trend towards the surface in these layers (ranging from -24.73 to $-23.53 \%$ in $\mathrm{K} 1$ and -25.96 to $-23.11 \%$ in K2) (Fig. 6c). Aquifer sediments had a relatively low organic matter with content around $0.05 \mathrm{wt} \%$, the $\delta^{13} \mathrm{C}_{\text {org }}$ values ranged between -27 and $-24 \%$. The $\mathrm{C} / \mathrm{N}$ ratios in the analyzed samples of both sediment profiles had a relatively narrow range between $\sim 4$ and $\sim 10$ (Figs. 6a and 7).

Slightly depleted $\delta^{13} \mathrm{C}_{\text {org }}$ values were measured in the unconfined aquifer in the depth range of $\sim 10 \mathrm{~m}$ to $\sim 30 \mathrm{~m}$ (average, $-26.1 \%$ o) compared to sediments from depths $\sim 40 \mathrm{~m}$ to $\sim 75 \mathrm{~m}$ (average, $-24.9 \%$ ). The highest TOC content (9.5 wt\%) was accompanied by the highest $\mathrm{C} / \mathrm{N}$ ratio (up to 32 ) in the peat layer at a depth of $28.4 \mathrm{~m}$. The $\delta^{13} \mathrm{C}_{\text {org }}$ values in peat layers from different depths varied from -26 to $-18 \%$ o (Fig. 6c).

\subsection{Arsenic and Fe in the sequential sediment extractions}

The extractable As in the sediments mainly included strongly adsorbed $\mathrm{As}\left(\mathrm{PO}_{4}{ }^{2-}\right.$-extractable) and $\mathrm{As}$ associated with $\mathrm{Fe}$ oxy(hydr)oxides (sum of $\mathrm{C}_{2} \mathrm{O}_{4}{ }^{2-}$-extractable and DCB-extractable) (Table 4). The clay sediments had much higher contents of strongly adsorbed $\mathrm{As}\left(8.3 \mathrm{mg} \mathrm{kg}^{-1}\right.$ on average $)$ and $\mathrm{Fe}$ oxy(hydr)oxides associated As $\left(8.9 \mathrm{mg} \mathrm{kg}^{-1}\right)$ compared to aquifer sand/silt (strongly-adsorbed As, $2.0 \mathrm{mg} \mathrm{kg}^{-1}$, As associated with Fe oxy(hydr)oxides: $2.8 \mathrm{mg} \mathrm{kg}^{-1}$ ). The releasable As and Fe was calculated as its sum in $\mathrm{S} 1$ to $\mathrm{S} 4$ since pyrite and phyllosilicate-incorporated As were relatively stable at anoxic conditions (Stuckey et al. 2015). The releasable As content, especially the strongly adsorbed As, was slightly higher in the unconfined aquifer sediments (depth, $\sim 10 \mathrm{~m}$ to $\sim 30 \mathrm{~m}$; average $5.4 \mathrm{mg} \mathrm{kg}^{-1}$ ) than in semi-confined aquifer sediments (depth, $\sim 40 \mathrm{~m}$ to $\sim 75 \mathrm{~m}$; average $3.6 \mathrm{mg} \mathrm{kg}^{-1}$ ). In contrast, the releasable $\mathrm{Fe}$ was slightly lower in the unconfined aquifer sediments, on average (average $4000 \mathrm{mg} \mathrm{kg}^{-1}$ in the unconfined aquifer and $4500 \mathrm{mg} \mathrm{kg}^{-1}$ in the semiconfined aquifer). Extractable As content had the highest concentration in the peat layers with up to $250 \mathrm{mg} \mathrm{kg}^{-1}$ and $140 \mathrm{mg} \mathrm{kg}^{-1}$, respectively (Fig. 6d). In both sediment profiles ( $\mathrm{K} 1$ and $\mathrm{K} 2)$, the ratio of releasable As/Fe ratio $\left(\mathrm{mmol} \mathrm{mol}^{-1}\right)$ increased towards to the surface (ranging from $\sim 0.5$ to $\sim 1.5$ ) (Fig. 6e).

\section{Discussion}

\subsection{Sediments and arsenic provenance}

Sediments in the Hetao Basin have a higher average As content $\left(11 \mathrm{mg} \mathrm{kg}^{-1}\right)$ in comparison with sediments from other river deltas in South and Southeast of Asia including the Ganges-Brahmaputra-Meghna delta, the Mekong delta, and the Red River delta that suffer from groundwater As contamination (Smedley and Kinniburgh 2002; Eiche et al. 2008; Neidhardt et al. 2013). This indicates that the As-bearing sediments in the Hetao Basin may have a different provenance
Fig. 5 Major and trace elements (a) as well as rare earth elements (REE) (b) in the sediments from $\mathrm{K} 1$ and $\mathrm{K} 2$ normalized to the mean concentration in the upper continental crust (UCC). The UCC value of each element was obtained from Rudnick and Gao (2003)
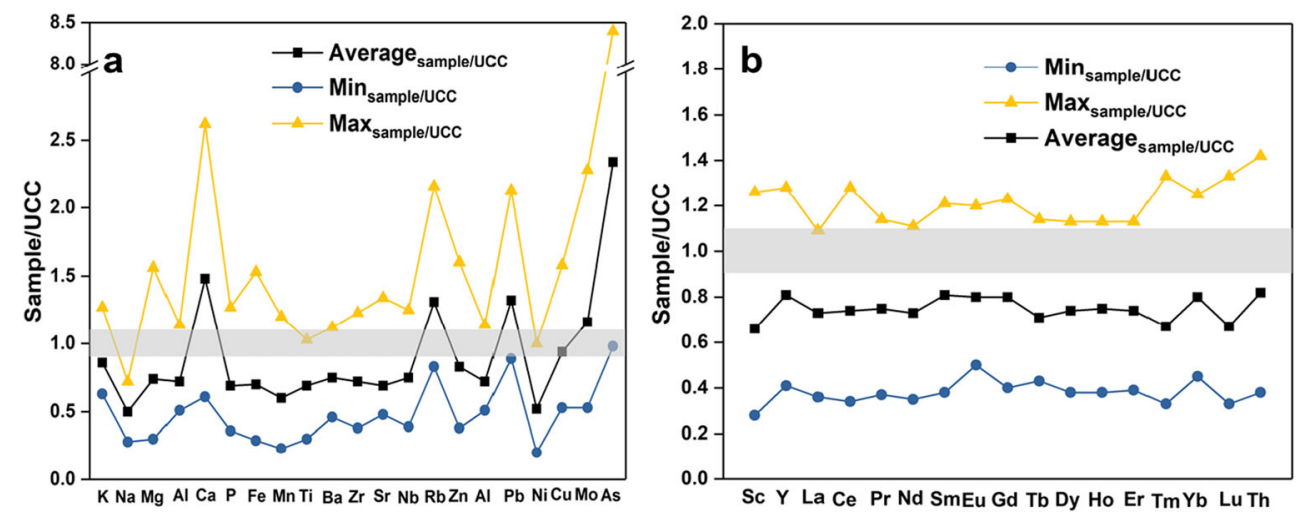


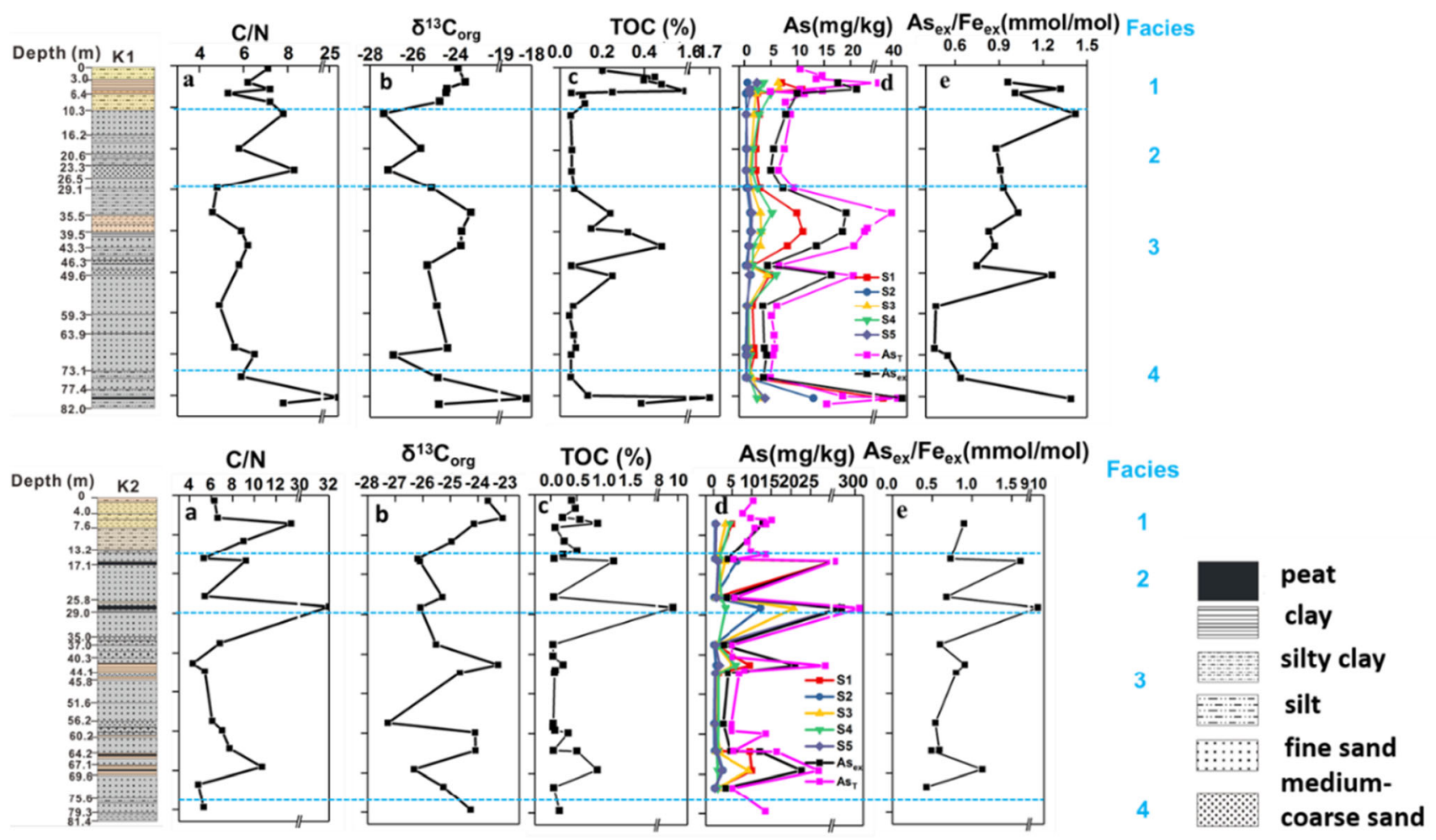

Fig. 6 Depth related variation of the $\mathrm{C}_{\text {org }} / \mathrm{N}$ ratio (a), $\delta{ }^{13} \mathrm{C}_{\text {org }}$ signature (b), TOC content (c), extractable As content in each sequential extraction step and the sum of As extracted in $\mathrm{S} 1$ to $\mathrm{S} 4(\mathbf{d})$, as well as $\mathrm{As}_{\mathrm{ex}} / \mathrm{Fe}_{\mathrm{ex}}$ ratio

compared to the other mentioned river deltas. Sediments provenance can be traced, amongst others, by REE pattern due to their strong resistance to geological processes including weathering, transport and sorting (André et al. 1986; Roddaz et al. 2006; Hofer et al. 2013). The small range of La/ $\mathrm{Yb}_{\text {chondrite }}(8.3-11.9)$ indicates that sediments of different depths originate from similar source rocks. Discriminant function analysis of major element geochemistry is independent of

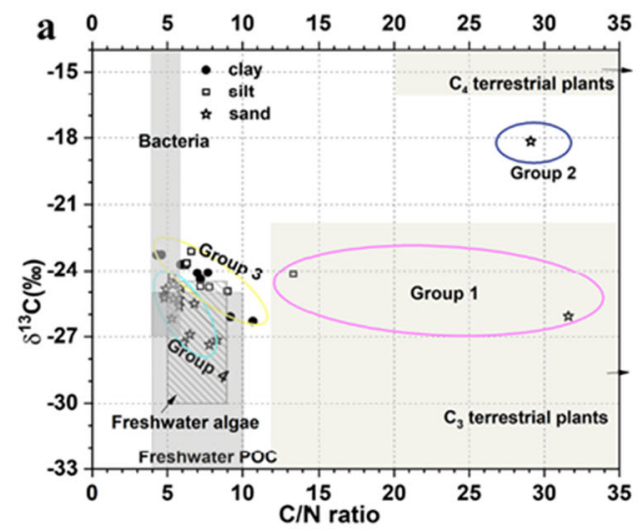

Fig. 7 Grouping of sediment samples based on $\delta^{13} \mathrm{C}_{\text {org }}$ signatures and $\mathrm{C}_{\text {org }} / \mathrm{N}$ ratios. In group 1, C3 terrestrial plants are the main organic matter source. Organic matter in group 2 gets contributions from $\mathrm{C} 3$ plants and $\mathrm{C} 4$ plants. Group 3 sediments have mixtures of freshwater POC and C3 terrestrial plants. Group 4 indicates freshwater POC as major organic $\left(\mathrm{mmol} \mathrm{mol}{ }^{-1}\right)(\mathbf{e})$ in selected samples. Lithology colors are displayed according to the visualized color in field. For more details on extraction chemicals and extractable phases in S1-S5 please refer to Table 1

grain sizes (Roser and Korsch 1988). In our case, it shows that sediments in the Hetao Basin are mainly of felsic igneous origin and experienced different sedimentary reworking.

The sediments have a similar REE content to gneiss and granite rocks from the Lang Mountains. More precise, the range of $\mathrm{La} / \mathrm{Yb}_{\text {chondrite }}$ with depleted $\mathrm{Eu}$ anomaly in comparison with chondrite is similar (Wang et al. 2016). However, bed-load sediments from the Yellow River have, on average, a

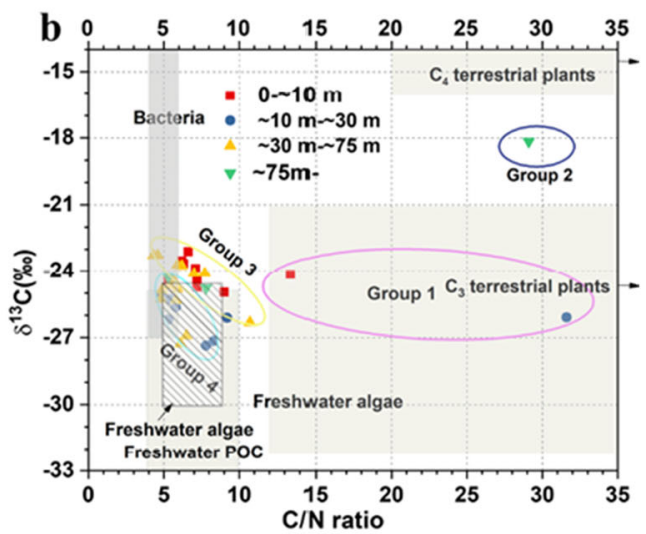

matter component in the sediment. The predominance fields of different sources of organic carbon are based on Lamb et al. (2006). a Samples from $\mathrm{K} 1$ and $\mathrm{K} 2$ boreholes are grouped according to lithologies. b Samples from K1 and K2 boreholes are grouped according to depths 
Table 4 Extractable As and Fe contents in each sequestration step (except peat layers)

\begin{tabular}{|c|c|c|c|c|}
\hline \multirow[t]{2}{*}{ Extraction phases } & \multicolumn{2}{|c|}{ sand $/$ silt $(n=18)($ average \pm SD $)$} & \multicolumn{2}{|c|}{ Silty clay/clay $(n=7)($ average \pm SD) } \\
\hline & As $\left(\mathrm{mg} \mathrm{kg}^{-1}\right)$ & $\mathrm{Fe}(\mathrm{wt} \%)$ & As $\left(\mathrm{mg} \mathrm{kg}^{-1}\right)$ & $\mathrm{Fe}(\mathrm{wt} \%)$ \\
\hline S1 (strongly adsorbed) & $2.0 \pm 1.8$ & $0.046 \pm 0.009$ & $8.3 \pm 2.7$ & $0.038 \pm 0.0102$ \\
\hline S2 (volatile sulfides, carbonates-precipitated) & $0.3 \pm 0.2$ & $0.037 \pm 0.019$ & $0.9 \pm 0.3$ & $0.007 \pm 0.002$ \\
\hline S3 (amorphous iron oxides and magnetite-precipitated) & $1.2 \pm 0.6$ & $0.202 \pm 0.155$ & $4.5 \pm 1.5$ & $0.583 \pm 0.228$ \\
\hline S4 (crystalline Fe oxides-precipitated) & $1.6 \pm 0.6$ & $0.186 \pm 0.041$ & $4.4 \pm 1.4$ & $0.413 \pm 0.135$ \\
\hline S5 (pyrite and part of sheet silicates-precipitated) & $0.6 \pm 0.2$ & $0.123 \pm 0.056$ & $1.3 \pm 0.6$ & $0.436 \pm 0.139$ \\
\hline Total extractable content & 5.7 & 0.594 & 18.1 & 1.477 \\
\hline Total sediments content & 7.3 & 2.470 & 23.7 & 6.485 \\
\hline
\end{tabular}

higher REE content and middle earth element (MREE) enrichment in comparison with UCC (Yang et al. 2002). Therefore, the sediments from Hetao Basin originate most likely from the Lang Mountains. Total As contents in gneiss and granite from the Lang Mountains range from 9.0 to $33 \mathrm{mg} \mathrm{kg}^{-1}$. Arsenic is mainly incorporated in Fe-containing minerals such as biotite and pyrite (Guo et al. 2016a; Liu et al. 2016). The indications here are consistent with previous suggestions that most groundwater As-enriched areas in or near sediment basins can be adjacent to orogenic belts with rocks containing Asenriched minerals (Mukherjee et al. 2008; Nordstrom 2009). Weathering of As-containing minerals from the Lang Mountains transfers As into Fe oxy(hydr)oxides or Mn oxides and clay minerals in the sediments. This is indicated by the clustering of As and major elements like Fe, Mn, Mg, Al, and trace elements $\mathrm{Ni}, \mathrm{Zn}, \mathrm{Cu}$, and $\mathrm{Pb}$. Iron and $\mathrm{Mn}$ are the major components of Fe oxy(hydr)oxides and $\mathrm{Mn}$ oxides, the $\mathrm{Mg}$ and $\mathrm{Al}$ of chlorite and illite. Furthermore, trace elements including $\mathrm{Ni}, \mathrm{Zn}, \mathrm{Cu}$, and $\mathrm{Pb}$ can be incorporated into $\mathrm{Fe}$ oxy(hydr)oxides or clay minerals (Fakhreddine et al. 2015).

\subsection{Depositional environment of the sediments}

The origin of organic carbon in the sediments of the Hetao Basin can be deduced based on the associations between $\mathrm{C} / \mathrm{N}$ ratio and $\delta^{13} \mathrm{C}_{\mathrm{org}}$ values of embedded organic matter (Lamb et al. 2006) (Fig. 7). In total, four different groups were distinguishable (Fig. 7). In general, organic matter embedded in the aquifer sediments results from freshwater particular organic matter (POC) or algae, indicating the aquatic deposit environment (Fig. 7a). Organic matter embedded in the depth interval from $\sim 10$ to $\sim 30 \mathrm{~m}$ was plotted in the algae or POC region (except peat layers), indicating sole aquatic origin (Fig. 7b). The decrease in the $\mathrm{C} / \mathrm{N}$ ratio with depths could be related to microbial decomposition, as microbes oxidize organic carbon to inorganic $\mathrm{CO}_{2}$. In this form, carbon can leave the aquifer (Meyers and Benson 1988). Slightly enriched $\delta^{13} \mathrm{C}_{\text {org }}$ values in the sediments at $\sim 30 \mathrm{~m}-\sim 75 \mathrm{~m}$ depth can be related to the terrestrial input from $\mathrm{C} 3$ plants, which were deposited by the paleo Yellow River during flooding period (Fig. 7b). This is consistent with the poor sorting of the grain sizes in these sediments. Sediment samples from surface or interbedded clay layers mostly plot in the group 3 (Fig. 7b), suggesting a considerable influence from terrestrial C3 plant input. These findings go in line with previous studies in the Red River and Mekong River delta (Eiche et al. 2017; Magnone et al. 2017). The increasing $\delta^{13} \mathrm{C}_{\text {org }}$ signatures towards the surface in the top silty clay or clay layers can be related to $\mathrm{C} 4$ plant debris input, as maize is the main $\mathrm{C} 4$ crop in the Hetao Basin nowadays.

Peat layers embedded in the sediments are dominated by terrestrial input (group 1 and group 2) (Fig. 7a). Peat bands at a depth of $16.7 \mathrm{~m}$ and $28.4 \mathrm{~m}$ in core $\mathrm{K} 2$ developed as response to the paleolake regression during LGM. The temporary lowering of the water table of local paleolakes in the LGM period allowed plant growth followed by burial within the sediments. Previous studies confirm that the peat layers with visually dark color are widely distributed at depth between $15 \mathrm{~m}$ and $30 \mathrm{~m}$ in the Hetao Basin (Deng 2008; Deng et al. 2011; Guo et al. 2016a, b). Pollen analysis of sediments deposited during the late Pleistocene also revealed that marsh areas developed locally resulting from lake level drop (Cai et al. 2019). While the peat layer in the unconfined aquifer at a depth of $28.4 \mathrm{~m}$ is influenced from $\mathrm{C} 3$ terrestrial input, the peat layer at a depth of $80.4 \mathrm{~m}$ is mainly composed of $\mathrm{C} 4$ terrestrial input. The change of vegetation type could be caused by climate change (Cai et al. 2019). It further indicates that the depositional environment of sediments at around $80 \mathrm{~m}$ is different compared to the sediments above.

\subsection{Facies interpretation and implications for As mobilization to the aquifer}

Based on similarities and differences in weathering intensities, geochemical composition, and depositional environment, the sediment profiles can be subdivided into four facies (Fig. 6). 


\subsubsection{Facies 1}

The surface and near surface sediments $(0 \sim 10 \mathrm{~m})$ are mainly composed of silty clay and clay. Stronger weathering intensities during the Holocene lead to a higher proportion of As that is adsorbed onto or incorporated into Fe oxy(hydr)oxides and clay minerals, consistent with higher As contents in the surface sediments (Fig. 6d). The oxic conditions in the surface sediments largely protect $\mathrm{Fe}$ oxy(hydr)oxides from reduction and thus strongly minimize the As release into porewater/groundwater. However, fluctuations in the groundwater table resulting from anthropogenic perturbations or seasonal fluctuations in the Hetao Basin (Guo et al. 2013) could cause frequent flooding of the surface sediments. As a consequence, occasional reduction of Fe oxy(hydr)oxides caused by a decreased redox potential may cause As release into porewater/groundwater, as indicated in other area such as Mekong Delta (Guo et al. 2013; Van Geen et al. 2013; Stuckey et al. 2015; Xiu et al. 2020).

\subsubsection{Facies 2}

Sediments in the depth interval from $\sim 10$ to $\sim 30 \mathrm{~m}$ were most likely formed during the LGM period with reduced chemical weathering intensities. The higher amount of releasable As, especially of strongly adsorbed As, in this facies compared to underlying sediments suggests that adsorption-desorption processes are important for controlling As concentrations in the groundwater (Radloff et al. 2011; Richards et al. 2019) (Fig. 6c). This goes in line with the generally higher groundwater As concentration (70\% of groundwater with As higher than $\left.10 \mu \mathrm{g} \mathrm{L}^{-1}\right)$ in the unconfined aquifer in this depth interval (Guo et al. 2008; Cao et al. 2018).

Organic matter embedded in this facies mainly results from in situ paleolake algae or POC (Fig. 7b). The in situ produced organic matter is more labile and thus more easily decomposed by microbes compared to terrestrial plant material (Nguyen et al. 2005). Microcosm experiments as well as groundwater microbial community studies suggested that microbial reduction of Fe oxy(hydr)oxides and As(V) species cause As to desorb from sediments into groundwater ( $\mathrm{Li}$ et al. 2014; Guo et al. 2015; Stolze et al. 2019; Xiu et al. 2020). Therefore, the reactive organic carbon and peat produced within paleolakes provide an easily available electron source for microbial reduction of $\mathrm{Fe}$ oxy(hydr)oxides (McArthur et al. 2001; Fendorf et al. 2010; Guo et al. 2019). This is consistent with the higher $\mathrm{Fe}^{2+}$ concentration in the groundwater that is high in dissolved As (Zhang et al. 2020; Qiao et al. 2020).

\subsubsection{Facies 3 and Facies 4}

Sediments in a depth from $\sim 30$ to $\sim 75 \mathrm{~m}$ are strongly influenced by fluvial deposition as indicated by the poor sorting of the grain sizes. The slightly higher content of releasable Fe can be related to the stronger weathering, which increases the release of Fe from Fe-containing silicates such as biotite. The released Fe can be reprecipitated as Fe oxy(hydr)oxides, therefore increasing the releasable Fe content. The formation of Fe oxy(hydr)oxides can incorporate As or provide As adsorption sites which further retards the As release into groundwater.

The interpretation of facies 4 is constrained by the limited number of samples and the unknown thickness of the layer. These sediments both from K1 and K2 are composed of silt or silty clay. Previous studies showed that a deep paleolake that was connected to the Yellow river existed in Hetao Basin between $\sim 60$ and $\sim 54 \mathrm{ka}$ (Chen et al. 2008; Yang et al. 2018). Sediments of the area have an age of $55.4 \pm 2.4 \mathrm{ka}$ at a depth of $76 \mathrm{~m}$ (Liu et al. 2014) (Table S1). Thus, facies 4 would fit to the typical paleolake sedimentation environment. The fine-grained sediments have to be considered as aquitard, and only limited wells in the Hetao Basin are target to this depth. Consequently, no significant influence on the dissolved As concentration in groundwater can be expected from this facies. Still, further drilling is necessary to better characterize this facies.

\section{Conclusion}

The As content in sediments from the Hetao Basin ranges from $\sim 5$ to $\sim 280 \mathrm{mg} \mathrm{kg}^{-1}$ with highest As contents in the peat layers. The REE pattern in the sediments indicates a possible origin sediment material from the Lang Mountains. Incipient to intermediate weathering of Asbearing rocks causes the As release from the Lang Mountains and its accumulation in the Hetao Basin sediments. More than $70 \%$ of $\mathrm{As}$ is $\mathrm{PO}_{4}{ }^{3-}$-displaceable or released by $\mathrm{Fe}$ oxy(hydr)oxides reduction indicates its high potential mobility. Ratios of $\mathrm{C}_{\text {org }} / \mathrm{N}$ combined with $\delta^{13} \mathrm{C}_{\text {org }}$ signatures show that organic matter that is embedded in the sediments was mainly produced in fresh water environments.

Four sediment facies can be distinguished. Sediments from a depth of $\sim 30 \mathrm{~m}$ to $\sim 75 \mathrm{~m}$ are significantly influenced by the fluvial deposition. Arsenic is less releasable in this facies. The sediments at depth of $\sim 10$ to $\sim 30 \mathrm{~m}$ is believed to be deposited during LGM where paleolakes regressed. Less reactive $\mathrm{Fe}$ phases with a higher content of releasable As presents in this facies. The higher content of potentially mobile As may explain the generally higher groundwater As concentration in this unconfined aquifer. Furthermore, reactive organic matter produced within the paleolake that makes up sediments of the unconfined aquifer probably simulates the reduction of $\mathrm{Fe}$ oxy(hydr)oxides and As(V) species, therefore increasing groundwater As concentration. 
Acknowledgments The authors give special thanks to students from China University of Geoscience (Beijing) for recording sediments properties in the field. We are also grateful for the measurements from N. Gill, G. Preuß, M. Kull, C. Mössner, and B. Oetzel from Karlsruhe Institute of Technology. We give thanks to the Graduate school for Climate and Environment (GRACE) in Karlsruhe Institute of Technology. Ms. Hongyan Wang is founded by China Scholarship Council. Furthermore, the authors are grateful for the constructive suggestions from editor Philip N. Owens and two reviewers.

Funding Information Open Access funding provided by Projekt DEAL.

\section{Compliance with ethical standards}

Conflict of interest The authors declare that they have no conflict of interest.

Research involving human participants and/or animals Human participants and animals are not involved in the research

Open Access This article is licensed under a Creative Commons Attribution 4.0 International License, which permits use, sharing, adaptation, distribution and reproduction in any medium or format, as long as you give appropriate credit to the original author(s) and the source, provide a link to the Creative Commons licence, and indicate if changes were made. The images or other third party material in this article are included in the article's Creative Commons licence, unless indicated otherwise in a credit line to the material. If material is not included in the article's Creative Commons licence and your intended use is not permitted by statutory regulation or exceeds the permitted use, you will need to obtain permission directly from the copyright holder. To view a copy of this licence, visit http://creativecommons.org/licenses/by/4.0/.

\section{References}

André L, Deutsch S, Hertogen J (1986) Trace-element and Nd isotopes in shales as indexes of provenance and crustal growth: the early Paleozoic from the Brabant Massif (Belgium). Chem Geol 57(12):101-115

Barth JA, Veizer J, Mayer B (1998) Origin of particulate organic carbon in the upper St. Lawrence: isotopic constraints. Earth Planet Sci Lett 162(1-4):111-121

Cai MT, Ye P, Yang X, Li C (2019) Vegetation and climate change in the Hetao Basin (northern China) during the last interglacial-glacial cycle. J Asian Earth Sci 171:1-8

Cao W, Guo HM, Zhang Y, Ma R, Li Y, Dong Q, Li Y, Zhao R (2018) Controls of paleochannels on groundwater arsenic distribution in shallow aquifers of alluvial plain in the Hetao Basin, China. Sci Total Environ 613:958-968

Chen FH, Fan YX, Chun X, Madsen DB, Oviatt CG, Zhao H, Yang LP, Sun Y (2008) Preliminary research on Megalake Jilantai-Hetao in the arid areas of China during the late quaternary. Chin Sci Bull 53: $1725-1739$

Deng Y (2008) Geochemical process of high arsenic groundwater system at western Hetao Basin. Dissertation China University of Geoscience

Deng Y, Wang Y, Ma T (2009) Isotope and minor element geochemistry of high arsenic groundwater from Hangjinhouqi, the Hetao Plain, Inner Mongolia. Appl Geochem 24(4):587-599
Deng YM, Wang Y, Ma T, Yang H, He J (2011) Arsenic associations in sediments from shallow aquifers of northwestern Hetao Basin, Inner Mongolia. Environ Earth Sci 64(8):2001-2011

Dowling CB, Poreda J, Basu AR, Peters SL, Aggarwal PK (2002) Geochemical study of arsenic release mechanisms in the Bengal Basin groundwater. Water Resour Res 38(9):1-12

Eiche E, Neumann T, Berg M, Weinman B, van Geen A, Norra S, Berner Z, Thi Kim Trang P, Hung Viet P, Stüben D (2008) Geochemical processes underlying a sharp contrast in groundwater arsenic concentrations in a village on the Red River delta, Vietnam. Appl Geochem 23(11):3143-3154

Eiche E, Berg M, Hönig SM, Neumann T, Lan VM, Pham TKT, Pham HV (2017) Origin and availability of organic matter leading to arsenic mobilisation in aquifers of the Red River Delta, Vietnam. Appl Geochem 77:184-193

Fakhreddine S, Dittmar J, Phipps D, Dadakis J, Fendorf S (2015) Geochemical Triggers of Arsenic Mobilization during Managed Aquifer Recharge. Environ Sci Technol 49(13):7802-7809

Fedo CM, Wayne Nesbitt H, Young GM (1995) Unraveling the effects of potassium metasomatism in sedimentary rocks and paleosols, with implications for paleo weathering conditions and provenance. Geol 23(10):921-924

Fendorf S, Michael HA, Van Geen A (2010) Spatial and temporal variations of groundwater arsenic in. South Southeast Asia Sci 328(5982):1123-1127

Fritz P, Fontes JC (1980) Handbook of environmental isotope geochemistry. In: Deines P (ed) The isotopic composition of reduced carbon. Elsevier, Amsterdam, pp 329-406

Fry B, Sherr EB (1984) $\delta{ }^{13} \mathrm{C}$ measurements as indicators of carbon flow in marine and freshwater ecosystems. Contrib Mar Sci 27:13-47

Guilliot S, Charlet L (2007) Bengal arsenic, an archive of Himalaya orogency and paleohydrology. J Environ Sci Health A 42:17851794

Guo H, Yang S, Tang X, Li Y, Shen Z (2008) Groundwater geochemistry and its implications for arsenic mobilization in shallow aquifers of the Hetao Basin, Inner Mongolia. Sci Total Environ 393(1):131-144

Guo H, Zhang B, Li Y, Berner Z, Tang X, Norra S, Stüben D (2011) Hydrogeological and biogeochemical constrains of arsenic mobilization in shallow aquifers from the Hetao basin, Inner Mongolia. Environ Pollut 159(4):876-883

Guo HM, Zhang Y, Xing L, Jia YF (2012) Spatial variation in arsenic and fluoride concentrations of shallow groundwater from the town of Shahai in the Hetao basin, Inner Mongolia. Appl Geochem 27(11): 2187-2196

Guo HM, Liu C, Lu H, Wanty RB, Wang J, Zhou YZ (2013) Pathways of coupled arsenic and iron cycling in high arsenic groundwater of the Hetao basin, Inner Mongolia, China: an iron isotope approach. Geochim Cosmochim Acta 112:130-145

Guo HM, Liu ZY,Ding SS, Hao CB, Xiu W, Hou WG (2015) Arsenate reduction and mobilization in the presence of indigenous aerobic bacteria obtained from high arsenic aquifers of the Hetao basin, Inner Mongolia. Environmental Pollution 203:50-59

Guo HM, Jia Y, Wanty RB, Jiang Y, Zhao W, Xiu W, Shen J, Li Y, Cao Y, Wu Y, Zhang D, Wei C, Zhang Y, Cao W, Foster A (2016a) Contrasting distributions of groundwater arsenic and uranium in the western Hetao basin, Inner Mongolia: implication for origins and fate controls. Sci Total Environ 541:1172-1190

Guo HM, Zhou Y, Jia Y, Tang X, Li X, Shen M, Lu H, Han S, Wei C, Norra S, Zhang F (2016b) Sulfur cycling-related biogeochemical processes of arsenic mobilization in the western Hetao Basin, China: evidence from multiple isotope approaches. Environ Sci Technol 50(23):12650-12659

Guo HM, Zhang D, Ni P, Cao Y, Li F, Jia Y, Li H, Wan L, Wang G (2017) On the scalability of hydrogeochemical factors controlling arsenic mobility in three major inland basins of PR China. Appl Geochem 77:15-23 
Guo HM, Li X, Xiu W, He W, Cao Y, Zhang D, Wang A (2019) Controls of organic matter bioreactivity on arsenic mobility in shallow aquifers of the Hetao Basin, PR China. J Hydrol 571:448-459

Hofer G, Wagreich M, Neuhuber S (2013) Geochemistry of fine-grained sediments of the upper Cretaceous to Paleogene Gosau Group (Austria, Slovakia): implications for paleoenvironmental and provenance studies. Earth Sci Front 4(4):449-468

Islam FS, Gault AG, Boothman C, Polya DA, Charnock JM, Chatterjee D, Lloyd JR (2004) Role of metal-reducing bacteria in arsenic release from Bengal delta sediments. Nature 430:68-71

Jia L, Zhang X, Ye P, Zhao X, He Z, He X, Zhou Q, Li J, Ye M, Wang Z, Meng J (2016) Development of the alluvial and lacustrine terraces on the northern margin of the Hetao Basin, Inner Mongolia, China: implications for the evolution of the Yellow River in the Hetao area since the late Pleistocene. Geomorphology 263:87-98

Keon NE, Swartz CH, Brabander DJ, Harvey C, Hemond HF (2001) Validation of an arsenic sequential extraction method for evaluating mobility in sediments. Environ Sci Technol 35(13):2778-2784

Krishnamurthy RV, Bhattacharya SK, Kusumgar S (1986) Palaeoclimatic changes deduced from $13 \mathrm{C} / 12 \mathrm{C}$ and $\mathrm{C} / \mathrm{N}$ ratios of Karewa lake sediments, India. Nature 323(6084):150-152

Lamb AL, Wilson GP, Leng MJ (2006) A review of coastal palaeoclimate and relative sea-level reconstructions using $813 \mathrm{C}$ and $\mathrm{C} / \mathrm{N}$ ratios in organic material. Earth-Sci Rev 75(1-4):29-57

Lambeck K, Rouby H, Purcell A, Sun Y, Sambridge M (2014) Sea level and global ice volumes from the Last Glacial Maximum to the Holocene. Proc Natl Acad Sci 111(43):15296-15303

Li Y, Guo HM, Hao C (2014) Arsenic release from shallow aquifers of the Hetao basin, Inner Mongolia: evidence from bacterial community in aquifer sediments and groundwater. Ecotoxicol 23(10): 1900-1914

Li B, Sun D, Xu W, Wang F, Liang B, Ma Z, Wang X, Li Z, Chen F (2017) Paleomagnetic chronology and paleoenvironmental records from drill cores from the Hetao Basin and their implications for the formation of the Hobq Desert and the Yellow River. Quat Sci Rev 156:69-89

Liu Z, Zhao H, Wang C, Ji Y, Zhang Y, Liu L, Zhao H, Bi Z, Liu H (2014) OSL ages of sedimentary layers in Linhe Depression since Late Pleistocene. Arid Land Geogr 37(3):439-446 Chinese with English abstract

Liu M, Zhang D, Xiong G, Zhao H, Di Y, Wang Z, Zhou Z (2016) Zircon $\mathrm{U}-\mathrm{Pb}$ age, $\mathrm{Hf}$ isotope and geochemistry of carboniferous intrusions from the Langshan area, Inner Mongolia: Petrogenesis and tectonic implications. J Asian Earth Sci 120:139-158

Magnone D, Richards LA, Polya DA, Bryant C, Jones M, van Dongen BE (2017) Biomarker-indicated extent of oxidation of plant-derived organic carbon $(\mathrm{OC})$ in relation to geomorphology in an arsenic contaminated Holocene aquifer, Cambodia. Sci Rep 7(1):1-12

McArthur JM, Ravenscroft P, Safiulla S, Thirlwall MF (2001) Arsenic in groundwater: testing pollution mechanisms for sedimentary aquifers in Bangladesh. Water Resour Res 37(1):109-117

McArthur JM, Nath B, Banerjee DM, Purohit M, Grassineau N (2011) Palaeosol Control on Groundwater Flow and Pollutant Distribution: The Example of Arsenic. Environ Sci Technol 45(4):1376-1383

McLennan SM (1993) Weathering and global denudation. J Geol 101(2): 295-303

Meyers PA, Benson LV (1988) Sedimentary biomarker and isotopic indicators of the paleoclimatic history of the Walker Lake basin, western Nevada. Org Geochem 13(4-6):807-813

Mukherjee A, Bhattacharya P, Savage K, Foster A, Bundschuh J (2008) Distribution of geogenic arsenic in hydrologic systems: controls and challenges. J Contam Hydrol 99:1-7

Mukherjee A, Verma S, Gupta S, Henke KR, Bhattacharya P (2014) Influence of tectonics, sedimentation and aqueous flow cycles on the origin of global groundwater arsenic: paradigms from three continents. J Hydrol 518:284-299
Neidhardt H, Biswas A, Freikowski D, Majumder S, Chatterjee D, Berner ZA (2013) Reconstructing the sedimentation history of the Bengal Delta Plain by means of geochemical and stable isotopic data. Appl Geochem 36:70-82

Nesbitt H, Young GM (1982) Early Proterozoic climates and plate motions inferred from major element chemistry of lutites. Nature 299(5885):715-717

Nguyen ML, Westerhoff P, Baker L, Hu Q, Esparza-Soto M, Sommerfeld M (2005) Characteristics and reactivity of algae-produced dissolved organic carbon. J Environ Eng (N Y) 131(11):1574-1582

Nickson R, McArthur J, Burgess W, Ahmed KM, Ravenscroft P, Rahman M (1998) Arsenic poisoning of Bangladesh groundwater. Nature 395:338

Nordstrom DK (2002) Worldwide occurrences of arsenic in ground water. Sci 296(5576):2143-2145

Nordstrom DK (2009) Natural arsenic enrichment: effects of diagenetic tectonichydrothermal cycle. Geol Soc Am Abstracts Progr 41(7): 217

Poulton SW, Canfield DE (2005) Development of a sequential extraction procedure for iron: implications for iron partitioning in continentally derived particulates. Chem Geol 214(3-4):209-221

Qiao W, Guo HM, He C, Shi Q, Xiu W, Zhao B (2020) Molecular evidence of arsenic mobility linked to biodegradable organic matter. Environ Sci Technol 54:7280-7290. https://doi.org/10.1021/acs.est. 0c00737

Quicksall AN, Bostick BC, Sampson ML (2008) Linking organic matter deposition and iron mineral transformations to groundwater arsenic levels in the Mekong delta, Cambodia. Appl Geochem 23(11): 3088-3098

Radloff KA, Zheng Y, Michael HA, Stute M, Bostick BC, Mihajlov I, Bounds M, Huq MR, Choudhury I, Rahman MW, Schlosser P (2011) Arsenic migration to deep groundwater in Bangladesh influenced by adsorption and water demand. Nat Geosci 4(11):793-798

Ravenscroft P, Brammer H, Richards K (2009) Arsenic pollution: a global synthesis. Wiley-Blackwell, Chichester

Richards LA, Casanueva-Marenco MJ, Magnone D, Sovann C, Dongen BE, Polya DA (2019) Contrasting sorption behaviors affecting groundwater arsenic concentration in Kandal Province, Cambodia. Geosci Front 10:1701-1713

Robert C, Kennett JP (1994) Antarctic subtropical humid episode at the Paleocene-Eocene boundary: clay-mineral evidence. Geology 22(3):211-214

Roddaz M, Viers J, Brusset S, Baby P, Boucayrand C, Hérail G (2006) Controls on weathering and provenance in the Amazonian foreland basin: insights from major and trace element geochemistry of Neogene Amazonian sediments. Chem Geol 226(1-2):31-65

Rodríguez-Lado L, Sun G, Berg M, Zhang Q, Xue H, Zheng Q, Johnson CA (2013) Groundwater arsenic contamination throughout China. Sci 341(6148):866-868

Roser BP, Korsch RJ (1988) Provenance signatures of sandstonemudstone suites determined using discriminant function analysis of major-element data. Chem Geol 67(1-2):119-139

Rudnick RL, Gao S (2003) The crust. Treatise Geochem 3:1-64

Salomons W, Mook WG (1981) Field observations of the isotopic composition of particulate organic carbon in the south- ern North Sea and adjacent estuaries. Mar Geol 41:11-20

Saunders JA, Lee MK, Uddin A, Mohammad S, Wilkin RT, Fayek M, Korte NE (2005) Natural arsenic contamination of Holocene alluvial aquifers by linked tectonic, weathering, and microbial processes. Geochem Geophys Geosyst 6(4):1-7

Smedley PL, Kinniburgh DG (2002) A review of the source, behaviour and distribution of arsenic in natural waters. Appl Geochem 17(5): $517-568$

Stolze L, Zhang D, Guo H, Rolle M (2019) Surface complexation modeling of arsenic mobilization from goethite: interpretation of an in-situ experiment. Geochim Cosmochim Acta 248:274-288 
Stuckey JW, Schaefer MV, Benner SG, Fendorf S (2015) Reactivity and speciation of mineral-associated arsenic in seasonal and permanent wetlands of the Mekong Delta. Geochim Cosmochim Acta 171: $143-155$

Tang J, Lin NF, Bian JM, Liu WZ, Zhang ZL (1996) Environmental geochemistry of arsenism areas in the Hetao plain, inner Mongolia. Hydrogeol Eng Geol 1:49-54 (In Chinese with English abstract)

Van Geen A, Rose J, Thoral S, Garnier JM, Zheng Y, Bottero JY (2004) Decoupling of As and Fe release to Bangladesh groundwater under reducing conditions. Geochim Cosmochim Acta 68:3475-3468

Van Geen A, Zheng Y, Goodbred S Jr, Horneman A, Aziz Z, Cheng Z, Stute M, Mailloux B, Weinman B, Hoque MA, Seddique A, Hossain M, Chowdhury S, Ahmed K (2008) Flushing history as a hydrogeological control on the regional distribution of arsenic in shallow groundwater of the Bengal Basin. Environ Sci Technol 42(7):2283-2288

Van Geen A, Bostick BC, Trang PTK, Lan VM, Mai NN, Manh PD, Viet PH, Radloff K, Aziz Z, Mey JL, Stahl MO, Harvey CF, Oates P, Weinman B, Stengel C, Frei F, Kipfer R, Berg M (2013) Retardation of arsenic transport through Pleistocene aquifer. Nature 501:204-207

Wang ZZ, Han BF, Feng LX, Liu B, Zheng B, Kong LJ (2016) Tectonic attribution of the Langshan area in western Inner Mongolia and implications for the Neoarchean-Paleoproterozoic evolution of the Western North China Craton: Evidence from LA-ICP-MS zircon U$\mathrm{Pb}$ dating of the Langshan basement. Lithos 261:278-295

Wang Y, Le Pape P, Morin G, Asta MP, King G, Bártová B, Suvorova E, Frutschi M, Ikogou M, Pham V, Vo P, Herman F, Charlet L (2018) Arsenic speciation in Mekong Delta sediments depends on their depositional environment. Environ Sci Technol 52(6):3431-3439

Wang HY, Guo HM, Xiu W, Bauer J, Sun GX, Tang XH, Norra S (2019a) Indications that weathering of evaporite minerals affects groundwater salinity and As mobilization in aquifers of the northwestern Hetao Basin, China. Appl Geochem 109:104416

Wang YH, Pi KF, Fendorf S, Deng YM, Xie XJ (2019b) Sedimentogenesis and hydrobiogeochemistry of high arsenic Late Pleistocene-Holocene aquifer systems. Earth-Sci Rev 189:79-98
Wen D, Zhang F, Zhang E, Wang C, Han S, Zheng Y (2013) Arsenic, fluoride and iodine in groundwater of China. J Geochem Explor 135:1-21

Winkel L, Berg M, Amini M, Hug SJ, Johnson CA (2008) Predicting groundwater arsenic contamination in Southeast Asia from surface parameters. Nat Geosci 1(8):536-542

Xie X, Wang Y, Ellis A, Liu C, Duan M, Li J (2014) Impact of sedimentary provenance and weathering on arsenic distribution in aquifers of the Datong basin, China: constraints from elemental geochemistry. J Hydrol 519:3541-3549

Xiu W, Lloyd J, Guo HM, Dai W, Nixon S, Bassil NM, Ren C, Zhang CR, Ke TT, Polya D (2020) Linking microbial community composition to hydrogeochemistry in the western Hetao Basin: potential importance of ammonium as an electron donor during arsenic mobilization. Environ Int 136:105489

Yang SY, Jung HS, Choi MS, Li CX (2002) The rare earth element compositions of the Changjiang (Yangtze) and Huanghe (Yellow) river sediments. Earth Planet Sci Lett 201(2):407-419

Yang X, Cai M, Ye P, Yang Y, Wu Z, Zhou Q, Li C, Liu X (2018) Late Pleistocene paleolake evolution in the Hetao basin, inner Mongolia, China. Quat Int 464:386-395

Zhang Z, Guo HM, Liu S, Weng HC, Han SB, Gao ZP (2020) Mechanisms of groundwater arsenic variations induced by extraction in the western Hetao Basin, Inner Mongolia, China. J Hydrol 583:124599

Zheng Y, Van Geen A, Stute M, Dhar R, Mo Z, Cheng Z, Horneman A, Gavrieli I, Simpson H, Versteeg R, Steckler M, Grazioli-Venier A, Goodbred S, Shahnewaz M, Shamsudduha M, Hoque M, Ahmed K (2005) Geochemical and hydrogeological contrasts between shallow and deeper aquifers in two villages of Araihazar, Bangladesh: implications for deeper aquifers as drinking water sources. Geochim Cosmochim Acta 69(22):5203-5218

Publisher's note Springer Nature remains neutral with regard to jurisdictional claims in published maps and institutional affiliations. 